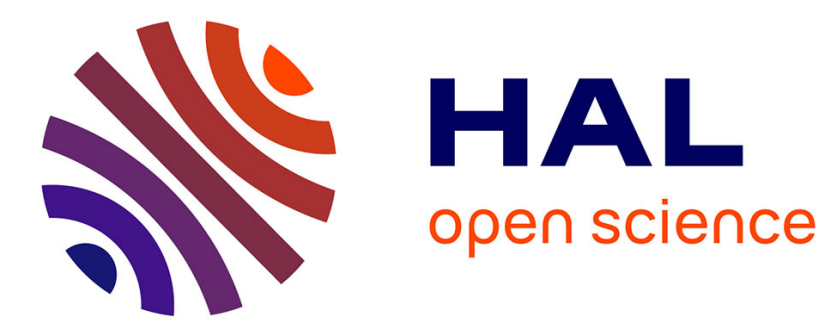

\title{
The deep structure of the Larderello-Travale Geothermal Field from 3D microearthquakes traveltime tomography
}

T. Vanorio, R. de Matteis, A. Zollo, F. Batini, A. Fiordelisi, B. Ciulli

\section{To cite this version:}

T. Vanorio, R. de Matteis, A. Zollo, F. Batini, A. Fiordelisi, et al.. The deep structure of the Larderello-Travale Geothermal Field from 3D microearthquakes traveltime tomography. Geophysical Research Letters, 2004, 31 (7), pp.L07613. 10.1029/2004GL019432 . hal-00407348

\section{HAL Id: hal-00407348 \\ https://hal.science/hal-00407348}

Submitted on 1 Feb 2021

HAL is a multi-disciplinary open access archive for the deposit and dissemination of scientific research documents, whether they are published or not. The documents may come from teaching and research institutions in France or abroad, or from public or private research centers.
L'archive ouverte pluridisciplinaire $\mathbf{H A L}$, est destinée au dépôt et à la diffusion de documents scientifiques de niveau recherche, publiés ou non, émanant des établissements d'enseignement et de recherche français ou étrangers, des laboratoires publics ou privés. 


\title{
The deep structure of the Larderello-Travale geothermal field from 3D microearthquake traveltime tomography
}

\author{
T. Vanorio, ${ }^{1}$ R. De Matteis, ${ }^{2}$ A. Zollo, ${ }^{3}$ F. Batini, ${ }^{4}$ A. Fiordelisi, ${ }^{4}$ and B. Ciulli ${ }^{4}$ \\ Received 7 January 2004; revised 22 February 2004; accepted 15 March 2004; published 8 April 2004.
}

[1] With the aim of exploring the deep structure of the Larderello-Travale (LT) geothermal field, a high resolution 3-D tomographic inversion of microearthquake traveltimes has been performed. Results show that the deep part of the Larderello-Travale field is characterized by the presence of a structure having a velocity range of $6.0-6.5 \mathrm{~km} / \mathrm{s}$ and a convex shape deepening towards the northeastern and the southeastern sides of the field. Earthquakes are mostly concentrated on the top of the high velocity structure and below the ' $K$ horizon' implying a transition of rheological properties at depth. The reported dependence on time of $\mathrm{t}_{s}-\mathrm{t}_{p}$ observed at one station located above an earthquake cluster suggests that the variation in pore fluid pressure might be responsible for the transition of rheological properties along the contact. In such an area, changes in pore fluid pressure might be related to time-dependent hydraulic mechanisms that are very effective in crustal rocks at elevated temperatures. INDEX TERMS: 7215 Seismology: Earthquake parameters; 7280 Seismology: Volcano seismology; 8045 Structural Geology: Role of fluids; 8180 Tectonophysics: Tomography; 8424 Volcanology: Hydrothermal systems. Citation: Vanorio, T., R. De Matteis, A. Zollo, F. Batini, A. Fiordelisi, and B. Ciulli (2004), The deep structure of the Larderello-Travale geothermal field from 3D microearthquake traveltime tomography, Geophys. Res. Lett., 31, L07613, doi:10.1029/2004GL019432.

\section{Introduction}

[2] The LT field, which produces geothermal electricity from hot steam, is emplaced on a structural high within the Northern pre-Apennine belt (Italy). Enel Green Power drilled 195 wells which have provided a fairly good knowledge of the relatively shallow structure (up to $\sim 3.5 \mathrm{~km}$ ) of the field.

[3] Since the early 1970s production from the shallow reservoirs has declined which, jointly with the growth of energy requirements during the eighty's, forced the exploration into fractured zones in the deeper basement. Of particular interest is a zone known as the ' $K$ horizon', which is manifested as a discontinuous high-amplitude reflector on seismic reflection lines [Batini and Nicolich, 1985; Brogi et al., 2003]. This horizon is regionally located,

\footnotetext{
${ }^{1}$ UMR-Géosciences Azur, Université de Nice, Sophia Antipolis, France. ${ }^{2}$ Dipartimento di Studi Geologici e Ambientali, Università del Sannio, Benevento, Italy.

${ }^{3}$ Dipartimento di Scienze Fisiche, Università di Napoli Federico II, Napoli, Italy.

${ }^{4}$ Enel Green Power, Pisa, Italy.
}

lying subhorizontally at depths varying beetween 8 and $10 \mathrm{~km}$. In the LT field its depth seems to vary between 3 and $6 \mathrm{~km}$ representing the upper boundary of a band of reflections which locally show 'bright spot' features. [Liotta and Ranalli, 1999]. Besides being discontinuous, the nature of this horizon is still an open issue: debate is still ongoing as to whether it is either a fractured zone containing supercritical fluids [Batini et al., 1985] or the top of a brittle-ductile transition with the presence of over-pressured fluids [Brogi et al., 2003]. The only direct evidence of an anomalous fluid pressure $(\sim 30 \mathrm{MPa})$ derives from the San Pompeo2 well that might have penetrated this horizon. Deeper parts of the well collapsed while finding fractured rocks at a depth of $2930 \mathrm{~m}$ filled with hot fluids trapped beneath phyllites and micaschists [Batini et al., 1985; Brogi et al., 2003].

[4] We show the results of a tomographic inversion of microearthquake traveltimes in the Larderello-Travale field to investigate its deep 3-D velocity structure and the earthquake distribution. Mapping a reliable earthquake distribution at depth, adjunctive information can be achieved that proves useful for the comprehension of the deep structure of this field.

\section{The Network and Data Inversion Method}

[5] Since 1977 the seismic activity in the field is monitored by a permanent seismic network operated by the Enel Green Power consisting of 26 stations, 3 of which have three-component sensors (Figure 1). We analyzed a dataset consisting of 500 microearthquakes having magnitude $M \geq 1.2$ that have occurred from January 1994 through September 2000. Arrival times measured from digitized seismograms are accurate to about $0.01 \mathrm{~s}$ for $\mathrm{P}$ - and $0.02 \mathrm{~s}$ for $\mathrm{S}-$ waves providing a database consisting of $\sim 7,000 \mathrm{P}$ - and $\sim 1,450 \mathrm{~S}$ - arrival time readings.

[6] The applied inversion procedure is described by Benz et al. [1996] and recently applied to several areas in the word [Okubo et al., 1997; Villasenor et al., 1998]. The method uses the finite differences technique [Podvin and Lecompte, 1991] to compute theoretical travel times by solving the Eikonal equation through a complex velocity structure and the least squares LSQR algorithm [Paige and Saunders, 1982] for simultaneous inversion of velocity parameters and hypocenter locations. Also, smoothing constraint equations are used to regularize the solution by controlling the degree of model roughness allowed during the inversion procedure.

[7] The 1-D reference velocity model, in Figure 2, has been obtained by a trial and error method based on the minimization of the RMS arrival time residuals. Information from geophysical data and VSP profiles [Batini et al., 1978] have been considered to limit the explored velocity range. 


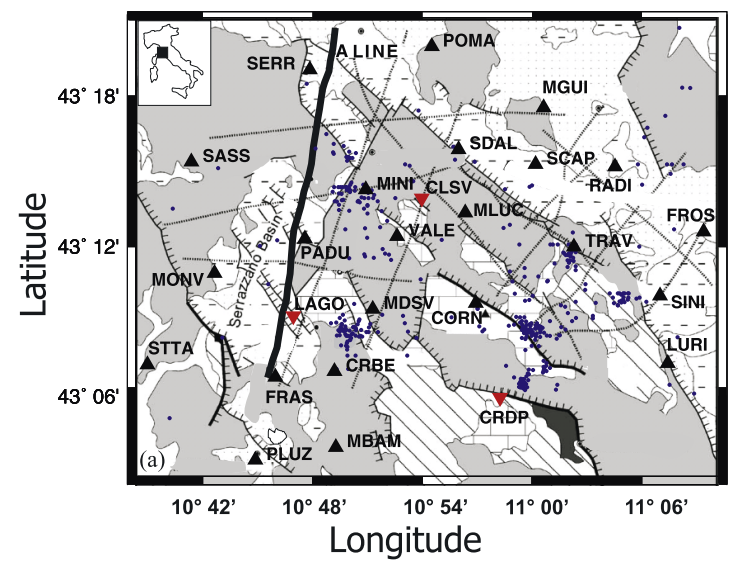

Figure 1. Map of the Larderello-Travale geothermal area showing seismic station (triangles) location (upside-down triangles are for three- component stations), epicenter location (circles) and, the seismic A line (thick line) [modified after Brogi et al., 2003 Reprinted with permission from Elsevier.].

From the initial data set, we selected earthquakes having at least $10 \mathrm{P}$ - phases read, azimuthal gap smaller than 180 and RMS of time residuals smaller than $0.5 \mathrm{~s}$. The selection resulted in 400 events having an average of $18 \mathrm{P}$ - traveltime readings and provided a final dataset consisting of 6,500 $\mathrm{P}$ first arrival times. The distribution of stations/events allowed to investigate a volume of $46 \times 36 \times 16 \mathrm{~km}^{3}$ with the top at $1 \mathrm{~km}$ above the sea level. The investigated volume has been discretized by using uniform velocity cells having size $1 \times 1 \times 1 \mathrm{~km}^{3}$.

\section{3D Images of the Larderello-Travale Structure}

[8] Figure 2 shows the map view of the three-dimensional P- velocity structure at four different depths. P- wave arrival time residuals as a function of distance and residual histograms are also shown in Figure 2 both for the initial
1D- (red points and red line, respectively) and for the final 3D- model (blue points and blue line, respectively). After 20 iterations, $\mathrm{P}$ - arrival time residuals were reduced by $45 \%$ from an initial RMS value of $0.08 \mathrm{~s}$. In order to verify the spatial resolution of the inferred 3D model, a standard checkerboard test has been performed. The result of the test for a checkerboard having cells $2 \times 2 \times 2 \mathrm{~km}^{3}$ and velocity of $\pm 0.15 \mathrm{~km} \mathrm{~s}^{-1}$ is also shown in Figure 2 . Test results show that anomalies having a dominant wavelength of $2 \mathrm{~km}$ are reasonably well recovered in the whole area up to $7-8 \mathrm{~km}$.

[9] Beneath the LT field, we found evidence of strong vertical and lateral $\mathrm{P}$ - wave velocity variations as velocity values span a range between 3.6 and $6.5 \mathrm{~km} \mathrm{~s}^{-1}$ (Figure 2 and Figure 3). Lower velocities (from 3.6 to $5.2 \mathrm{~km} \mathrm{~s}^{-1}$ ) are mainly located around the Lago, Miniera, and PaduleTravale areas up to $2 \mathrm{~km}$ depth and imply the presence of fractured and steam-bearing formations [Ito et al., 1979]. Instead, a structure having higher velocity (from 5.3 to $6.4 \mathrm{~km} \mathrm{~s}^{-1}$ ) which, as depth increases, spreads out over the area, is found at greater depth. This structure deepens from the Lago area towards the NE and SE suggesting a convex shape. The map of Bouguer anomalies in Figure 2 shows a nearly circular low gravity anomaly surrounding higher gravity anomalies. In the same figure, a contour map of the depth to the ' $K$ horizon', as inferred by the analysis of seismic reflection data [Barelli et al., 2000], is presented as well. The structure is dominated by a large anticline both trending NE-SW with flanks falling off steeply in both directions having two smaller peaks inside the structure at $\sim 3.5 \mathrm{~km}$. Note that the San Pompeo 2 well is located near the western gravity high.

[10] Figure 3 shows the result of three merged crosssections along the directions reported in Figure 2 and reports the comparison with the ' $K$ horizon' only where this zone has been clearly detected on seismic profiles [Brogi et al., 2003]. It is worth noting that seismicity mostly lies along the contact between the deeper high velocity structure and the overlying lower velocity zone. Earthquake location and velocity images, reported in this study, have
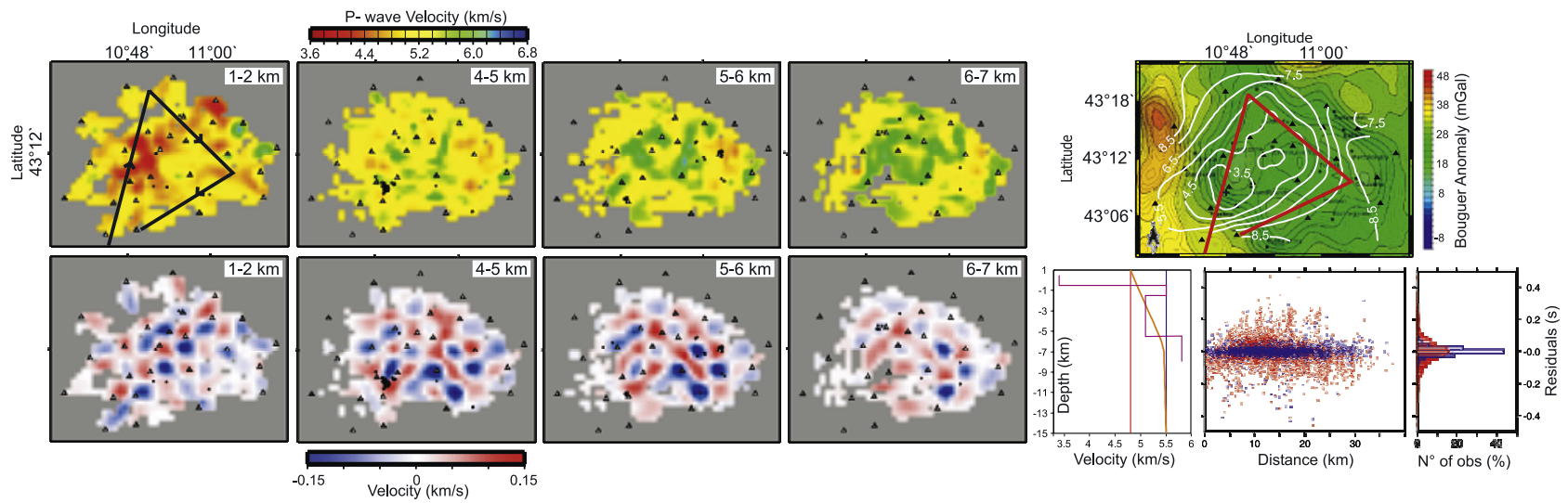

Figure 2. Maps of P- wave velocity and Bouguer gravity anomalies (top) and checkerboard tests (bottom). Each velocity layer is $1 \mathrm{~km}$ thick and cells not sampled by any ray are represented in gray. Symbol "+" indicates the location of San Pompeo 2 well. Bottom left: The reference 1D P-velocity model used for the 3-D tomografic inversion (orange line). Higher and lower velocity bounds (red and blue lines) obtained by plotting time residuals and VSP data (magenta line). Bottom right: P-arrival time residuals as a function of distance and residual histogram referring both to the initial 1D model (reddots and line) and to the final 3D model (blue- dots and lines). 


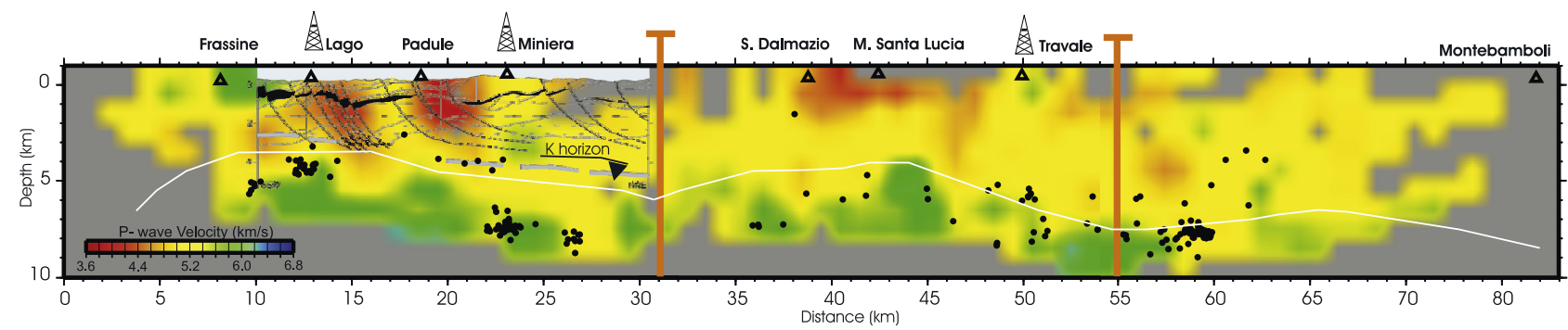

Figure 3. Merged P- velocity cross-sections along the directions shown in Figure 2. Triangles and dots represent station and earthquake locations, respectively. The seismic A line whose direction is reported in Figure 1 is also displayed for comparison: the dashed gray line represents the $K$ horizon structure as inferred from Brogi et al. [2003]. The white solid line delineates the top of the $K$ horizon reported in Figure 2 as inferred by Barelli et al. [2000].

been obtained by using only $\mathrm{P}$ - arrival time data recorded by a dense network. The lack of S- data can generally be a cause for errors in the estimate of earthquake location parameters. In order to verify the reliability of earthquake locations, an ad hoc test has been performed: synthetic traveltimes were computed by using the local network geometry, the final- 3-D velocity model and earthquake locations. Events were then re-located in the 3-D velocity model using the synthetic dataset. As a trial starting solution, the locations obtained in different $1-\mathrm{D}$ velocity models were used. The comparison between the test result and the initial earthquake coordinates is shown in Figure 4, demonstrating well constrained solutions can be obtained using only P- data from the dense Larderello network.

\section{Discussion and Concluding Remarks}

[11] The 3-D tomographic inversion performed in the LT field has imaged a deep high velocity structure. Elter and Pandeli [1990] report that below the sedimentary cover, the crystalline basement is subdivided into two tectonic units: the upper unit consists mostly of quartzites, phyllites and micaschists affected by metamorphism while the gneiss complex constitutes the lower unit. The upper unit of the crystalline basement has been reached by the San Pompeo well and correlated to the reflective ' $K$ horizon' retrieved at this depth by seismic surveying [Brogi et al., 2003]. Also, on the basis of local and anomalous pressure encountered in the San Pompeo well, as well as of temperature data extrapolated from those measured in shallower wells, Liotta and Ranalli [1999] postulated that the ' $K$ horizon' might signify a brittle-ductile transition rather than a lithologic variation if over-pressured fluids are invoked.

[12] Results from this study show that the shape of the high velocity structure follows the ' $K$ horizon' [Barelli et al., 2000] along all the profile shown in Figure 3 (white line). In particular, the ' $K$ horizon' [Barelli et al., 2000; Brogi et al., 2003] lies within the lower velocity zone just above both the high velocity structure and the earthquake locations. On this basis, we argue that the deep high velocity structure might correspond either to stronger lithology variations or to less fractured parts of the crystalline basement. In order to verify the possibility that hot fluids might be trapped below the phyllite and micaschist formations, we have investigated a possible signature on velocity.
[13] Using Vp velocity information alone can be ambiguous because a low P-wave velocity can be due both to overpressure and to the presence of gas. Prasad [2002] and Dvorkin et al. [1999] have shown that the $\mathrm{Vp} / \mathrm{Vs}$ ratio helps to differentiate between the two cases. We report in Figure 5 the variation of $\mathrm{t}_{s}-\mathrm{t}_{p}$, which is proportional to both $\mathrm{Vp} / \mathrm{Vs}$ and hypocentral depth, as a function of time. Data refer to events located in a space of $1 \times 1 \times 1 \mathrm{~km}^{3}$, whose center is at $4 \mathrm{~km}$ depth, under the vertical direction of the three-component LAGO station. To take into account the spatial offset between events, values of $t_{s}-t_{p}$ have been corrected as though they had nucleated from a common origin whose location is in the center of the cluster. Figure 5 shows a quasi- cyclic fluctuation of $\mathrm{t}_{s}-\mathrm{t}_{p}$ as a function of time whose order of magnitude is equal to $\sim 0.2 \mathrm{~s}$. The estimate of uncertainties on location of $<0.25 \mathrm{~km}$ (Figure 4) suggests that such a fluctuation can not be related to errors in location. If this fluctuation was due to mislocalization, it would imply a location error

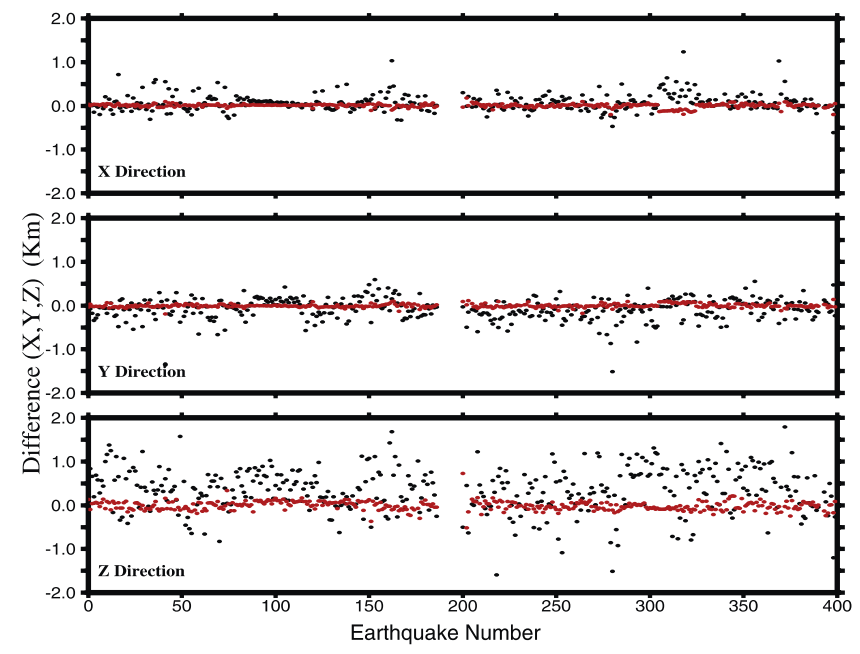

Figure 4. Test results showing the difference, along the $x$, $y$, and $z$ directions, between localizations in the final 3D tomographic model and those obtained by inversion of synthetic traveltimes (red dots). Differences before the inversion procedure are also reported for comparison (black dots). The estimated error on localizations results to be $<0.25 \mathrm{~km}$. 


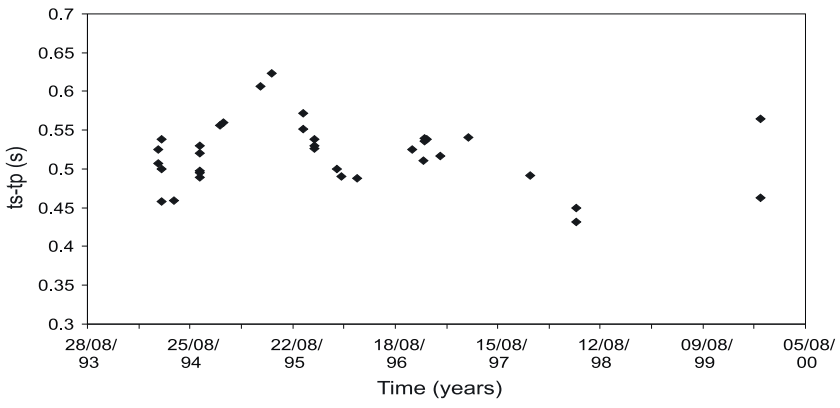

Figure 5. Variation of $\mathrm{t}_{s}-\mathrm{t}_{p}$ as a function of time at the LAGO station.

equal to $\sim 1.5 \mathrm{~km}$. Therefore, we attribute such a fluctuation as being due to a variation of the $\mathrm{Vp} / \mathrm{Vs}$ ratio which, for a $\Delta\left(\mathrm{t}_{s}-\mathrm{t}_{p}\right)$ of $0.2 \mathrm{~s}$, is equal to \pm 0.3 . As reported by Nur and Walder [1990], the state of crustal porosity, permeability and, fluid content is transient. This is mostly true in hydrothermal zones where healing and sealing processes responsible for pathway clogging are fast enough [Smith and Evans, 1984; Summers et al., 1978]. Through such a mechanism, if permeability is low and its rate of reduction with porosity is relatively fast, the pore pressure of the trapped fluids will rapidly rise to overcome the least principal stress, leading to 1) natural hydrofracturing (increase of $\mathrm{t}_{s}-\mathrm{t}_{p}$ ) accompanied by release of fluids, 2) drop in pore pressure accompanied by loss of porosity (i.e., crack closure) due to compaction (decrease of $\mathrm{t}_{s}-\mathrm{t}_{p}$ ). Several studies [Kanamori and Heaton, 2000; Hickman et al., 1995; Cheng and Nur, 1992] show that thermal pressurization may play a relevant role in faulting and earthquake processes. This mechanism is particularly required in the case of sub-horizontal crustal reflectors as they are mechanically very difficult to explain unless high pore pressure is involved [see Hickman et al., 1995, and references therein]. Other weakening processes such as the syntectonic alteration of deformation zones having a weaker mineralogy with strong preferred orientation [Wintsch et al., 1995] as micashists and fluid-assisted deformation mechanisms at hydrothermal conditions [Blanipied et al., 1995] may also play an important role.

[14] By providing a 3-D lateral velocity variation of the Larderello-Travale deep structure, this study will be useful to enhance the seismic reflection data processing that, in complex geological settings, has to deal with the trade-off between the stacking- and rms- velocities [Lynn and Claerbout, 1982]. Furthermore, the earthquake location in the $3-\mathrm{D}$ velocity model provided evidence that seismicity is distributed in a range from $4 \mathrm{~km}$ to $8 \mathrm{~km}$ depth between the deep high velocity structure on the one hand and, the ' $K$ horizon' on the other. This latter together with the reported $t_{s}-t_{p}$ fluctuation suggests that this zone may contain fluids whose pressure changes over time. We postulate that pressure changes are due to time-dependent hydraulic mechanisms.

[15] Acknowledgments. We are grateful to H. Benz for having provided the 3-D tomographic code. G. Giberti, F. Lancieri and L. Cantore contributed to the picking of data. This work was performed under the auspicies of the GNV-INGV (FP2000-2003) and Department of Civil Protection. T. Vanorio has been supported by a MC Fellowship of the European Community program (HPMF-CT-2002-01777).

\section{References}

Barelli, A., G. Bertini, G. Buonasorte, G. Cappetti, and A. Fiordelisi (2000), Recent deep exploration results at the margins of the Larderello-Travale geothermal system, paper presented at Proceedings of the 2000 World Geothermal Congress, Int. Geother. Assoc., Tohoku, Japan.

Batini, F., and R. Nicolich (1985), P and S reflection seismic profiling and well logging in the Travale geothermal field, Geothermics, 14, 731-747.

Batini, F., P. D. Burgassi, G. M. Cameli, R. Nicolich, and P. Squarci (1978), Contribution to the study of the deep lithospheric profiles: Deep reflecting horizons in Larderello-Travale geothermal field, Mem. Soc. Geol. Ital., 19, 477-484.

Batini, F., G. Bertini, G. Giannelli, E. Pandeli, M. Puxeddu, and I. Villa (1985), Deep structure, age and evolution of the Larderello-Travale geothermal field, Trans. Geotherm. Resourc. Counc., 9, 253-259.

Benz, H. M., B. A. Chouet, P. B. Dawson, J. C. Lahr, R. A. Page, and J. A. Hole (1996), Three-dimensional P and S wave velocity structure of Redoubt Volcano, Alaska, J. Geophys. Res., 101, 8111-8128.

Blanipied, M. L., D. A. Lockner, and J. D. Byerlee (1995), Frictional slip of granite at hydrotheral conditions, J. Geophys. Res., 100, 13,045-13,064.

Brogi, A., A. Lazzarotto, D. Liotta, and G. Ranalli (2003), Extensional shear zones as imaged by reflection seismic lines: The Larderello geothermal field (central Italy), Tectonophysics, 363, 127-139.

Cheng, Q., and A. Nur (1992), Pore fluid pressure effects in anisotropic rocks: Mechanism of induced seismicity and weak faults, Pure Appl. Geophys., 139, 463-479.

Dvorkin, J., G. Mavko, and A. Nur (1999), Overpressure detection from compressional- and shear-wave data, Geophys. Res. Lett., 26, $3417-$ 3420 .

Elter, F. M., and E. Pandeli (1990), Alpine and Hercynian orogenic phases in the basement rocks of the northern Apennines (Larderello geothermal field, southern Tuscany, Italy, Eclogae Geol. Helv., 83, 241-264.

Hickman, S., R. Sibson, and R. Bruhm (Eds.) (1995), Mechanical involvement of fluids in faulting, J. Geophys. Res., 100, 12,831-13,132.

Ito, H., J. DeVilbiss, and A. Nur (1979), Compressional and shear waves in saturated rock during water-steam transition, J. Geophys. Res., 84, 47314735.

Kanamori, H., and T. H. Heaton (2000), Microscopic and macroscopic physics of earthquakes, in Geocomplexity and the Physics of Earthquakes, Geophys. Monogr. Ser, vol. 120, edited by J. B. Rundle, D. L. Turcotte, and W. Klein, pp. 147-163, AGU, Washington, D. C.

Liotta, D., and G. Ranalli (1999), Correlation between seismic reflectivity and reology in extended lithosphere: Southern Tuscany, inner northen Apennines, Italy, Tectonophysics, 315, 109-122.

Lynn, W. S., and J. F. Claerbout (1982), Velocity estimation in laterally varying media, Geophysics, 47, 884-897.

Nur, A., and J. Walder (1990), Time-dependent hydraulics of the Earth's crust, in The Role of Fluids in Crustal Processes, pp. 113-127, Natl. Acad. Press, Washington, D. C.

Okubo, P. G., H. M. Benz, and B. A. Chouet (1997), Imaging the crustal magma sources beneath Mauna Loa and Kilauea volcanoes, Hawaii, Geology, 25, 867-870.

Paige, C. C., and M. A. Saunders (1982), LSQR: An algorithm for sparse linear equations and sparse least squares Trans, Math. Software, 8, 4371.

Podvin, P., and I. Lecompte (1991), Finite difference computation of traveltimes in very contrasted velocity models: A massively parallel approach and its associated tools, Geophys. J. Int., 105, 271-284.

Prasad, M. (2002), Acoustic measurements in sands at low effective pressure: Overpressure detection in sands, Geophysics, 67, 405-412.

Smith, D. L., and B. Evans (1984), Diffusional crack healing in quartz, J. Geophys. Res., 89, 4125-4135.

Summers, R., K. Winkler, and J. Byerlee (1978), Permeability changes during the flow of water through westerly granite at temperatures of $100^{\circ}-400^{\circ} \mathrm{C}, \mathrm{J}$. Geophys. Res., 83, 339-344.

Villasenor, A., H. M. Benz, L. Filippi, G. De Luca, R. Scarpa, G. Patane, and S. Vinciguerra (1998), Three-dimensional P wave velocity structure of Mt. Etna, Italy, Geophys. Res. Lett., 25, 1975-1978.

Wintsch, R. P., R. Christoffersen, and A. K. Kronenberg (1995), Fluid-rock reaction weakening of faut zones, J. Geophys. Res., 100, 13,021-13,032.

R. De Matteis, Dipartimento di Studi Geologici e Ambientali, Università del Sannio, Benevento, Italy.

F. Batini, B. Ciulli, and A. Fiordelisi, Enel Green Power, Via Andrea Pisano, 120, I-56122 Pisa, Italy.

T. Vanorio, UMR-Geosciences Azur, Université de Nice, Sophia Antipolis, 250 Rue Albert Einstein, F-06560 Valbonne, France. (vanorio@ geoazur.unice.it)

A. Zollo, Dipartimento di Scienze Fisiche, Università di Napoli Federico II, I-80125 Napoli, Italy. 